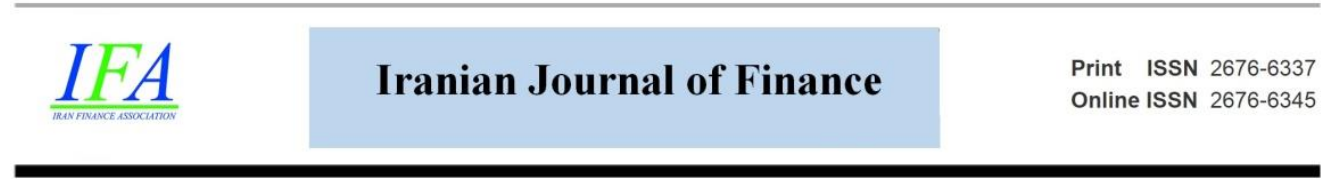

\title{
Earnings Decomposition, Value Relevance and Predictability
}

\author{
Sasan Babaie* \\ *Corresponding Author, Assistant prof., Faculty of Economics and \\ Accounting, Central Tehran Branch, Islamic Azad University, Tehran, Iran. \\ (Email: sbabaei2009@yahoo.com) \\ Document Type: Original Article \\ Received: 2020/12/14 Accepted: 2021/05/28 \\ 2021, Vol. 5, No. 4. 107-127. \\ Published: 2021/12/05
}

\begin{abstract}
Compared with net earnings, the components of earnings are more informative in companies whose components have different qualities of persistence and volatility. We examine the issue of whether net earnings together with their components have more information content than only net earnings. We construct a model to describe the effect of components volatility and their persistence through disaggregation of earnings value relevance and predictability. The analyses in our study are based on 600 firm-year observations in Tehran Stock Exchange (TSE) for the period 2005- 2019. Data are derived from RAHAVARD NOVIN Iranian software and firms' financial statements. The statistical tests for data analyses are the difference of means test (t-test) and regression analyses. The results of the current study indicate that as the persistence and volatility of selected components of earnings (sales, employee expenses, other selling, general and administrative expenses, and income taxes) increase, earnings disaggregation can improve earnings predictability. Furthermore, when the volatility of employee expenses increases, disaggregated earnings can improve earnings value relevance. As the value relevance of net earnings has been declined over the past decades, the results of the current study suggest that earnings disaggregation plays a major role in improving earnings value relevance and their predictability.
\end{abstract}

Keywords: Earnings Components, Value Relevance, Predictability, Persistence, Volatility

DOI: https://doi.org/10.30699/IJF.2021.230387.1124 Publisher: Iran Finance Association Copyright: author(s) Type of License: Creative Commons License (CC-BY 4.0) 


\section{Introduction}

Most value relevance texts are concerned with how accounting metrics affect the change in the market value measures, including the stock returns. The measure in question is generally net earnings (Beisland, 2009). Net earnings are one of the important pieces of financial information that is provided in income statements. Earnings are commonly applied as a summary measure of firms' operating performance (Chandra \& Ro, 2008). Previous research has suggested that all components of earnings have the same value relevance. A lot of research studies have shown that this is not necessarily the case (Beisland, 2009). If an earnings component has different properties from other components of earnings, aggregation of amounts will cause the loss of information content (Schiemann \& Geunther, 2013). Disaggregating earnings into their more persistent components can increase the predictability of earnings (Bratten, 2009). Similar to this notion, Dichev and Tang (2009) suggest that the higher the earnings volatility, the lower the persistence and predictability in future earnings. Furthermore, Schiemann and Guenther (2013) argue that an increase in volatility of large cost components directly increases the volatility of earnings volatility, which leads to a decrease in earnings predictability and value relevance. As the value relevance of net earnings has been declined over the past decades, in this research, we examine the effect of volatility and persistence of key earnings components on earnings value relevance and predictability through disaggregation and construct a model for this effect.

\section{Research Background}

According to IASB's framework, providing high-quality information in financial reporting has a positive effect on capital suppliers and other stakeholders in making decisions, and thus increases the efficiency of a capital market (Beest, Braam and Boelens, 2009). A company's earnings as a key measure is a main source of information in the evaluation of business performance. Hence, high-quality reported earnings are needed, especially for making investments and other decisions (Wan Ismail, Kamarurin, \& Sarman,2015). Earnings quality can be defined as "the extent to which reported earnings reflects economic realities (Krishnan \& Parsons, 2008). Typically, earnings quality can be classified into eight measures: persistence, predictability, quality of accruals, volatility, earnings management, value relevance, timeliness and (conditional) conservatism (Pronobis, Schwetzler, Sperling, \& Zulch,2008). 
Providing relevant information to estimate the value of a company is among the objectives of financial reporting, and studies into value relevance analyse whether this objective is met. Value relevance explains how the information presented in financial statements can determine the value of a firm. (Beisland, 2009). Earnings predictability can be defined as the capacity of earnings to explain its changes over a period of time (Lipe, 1990). If you could use past earnings to estimate current earnings, then predictability would be high. A more accurate prediction of future dividends can be made by a good estimate of future earnings, which increases the preciseness of an estimated share price as a proxy for the present value of expected future dividends (Schiemann \& Geunther, 2013). There is a negative relationship between earnings persistence and earnings volatility. Increasing earnings volatility can reduce its predictability, while earnings predictability is positively associated with earnings persistence. (Clubb \& Wu, 2014).

The value relevance of earnings has been declined over the past decades. Instead of an income statement approach, which is based on historical cost and matching principles, regulators have emphasized the balance sheet approach, which is followed by fair values. (Bratten, 2009). Ahmadi and Bouri (2018) show that the value relevance of book value is statistically greater than EPS models. So, the question is how the decline in value relevance and persistence of earnings can be compensated? Reported aggregate amounts such as net earnings and book value of shareholders' equity are among the criteria considered by investors. However, these aggregated measures are sometimes separated into components. The value relevance of various components of earnings may be different (Beisland, 2009), and if there is a relationship between one of those components and future earnings, taking the information related to this component into account will result in a more accurate estimate of future earnings. If two components have the same attributes such as the same persistence, these components can be summed up without losing information content. However, if a component has different attributes from other components, the aggregation of components will cause the loss of information content. In this situation, considering a component separately would be more useful(Schiemann \& Geunther, 2013). Burke, Warfield, and Wieland (2020) argue that a possibly significant form of disaggregating financial information is to decompose the change in earnings measures into their primary performance drivers. They argue that volume and rate variances can be used to predict future net interest earnings and there is a positive relationship among those variables and stock returns and prices, implying the value relevance of decomposed information. Lipe (1986) decomposes earnings into its components (gross 
earnings, depreciation expense, selling, general and administrative expenses, income taxes, interest expenses, and other earnings items), and suggests that decomposing the unexpected component shocks better explains unexpected returns and that the response coefficient of each component's earnings shock is linked to its persistence (Bratten, 2009). Schiemann and Guenther (2013) confirm that employee expenses add to the predictability of subsequent earnings. They further provide evidence that there is a positive link between the persistence of employee expenses and earnings predictability and therefore their value relevance. Bratten (2009) provides evidence on how information from components of earnings is considered by investors and analysts (sales revenues, cost of goods sold, selling, general and administrative (SGA) expenses, depreciation, interest expenses, income tax, non-operating expenses, minority interest and other items). He finds that disaggregation is better at earnings predictability than aggregated earnings and less disaggregation.

Among Iranian studies, Hashemi, Amiri, \& Moinghafghazi (2013) argue that if earnings changes are broken down into their underlying components by means of the residual earnings concept, these components increase earnings value relevance. Hosseinzadeh and Ahmadinia (2009) study the value relevance of components, such as income before taxes, operating income, net earnings and accrual items, and suggest that except for accrual items, all the components are value relevant. Furthermore, Shahryari, Barzideh, \& Elhami(2015) conclude that operating and non-operating income is increasingly value-relevant. Etemadi, Azar, Sepasi, and Babaie (2018) show that higher persistence and lower volatility of components will increase earnings predictability, and among the main components used in the study, sales, cost of goods sold, employee expenses, depreciation, other SGA expenses, and financial expenses improve earnings predictability. Jafari (2009) studies the value relevance of components of earnings, such as sales revenues, gross earnings, operating income, income before taxes and net earnings, and suggests that only operating income and gross earnings are significantly valuerelevant. In addition, Valipour, Rostami, and Shahabi (2010) study the value relevance of earnings components, including sales, gross earnings, operating income, income before taxes and net earnings, and conclude that these components add to earnings value relevance.

Overall, previous studies show that earnings disaggregation can improve earnings predictability and its value relevance. The question is how earnings volatility and persistence components can affect those qualities of earnings (Figure 1). 


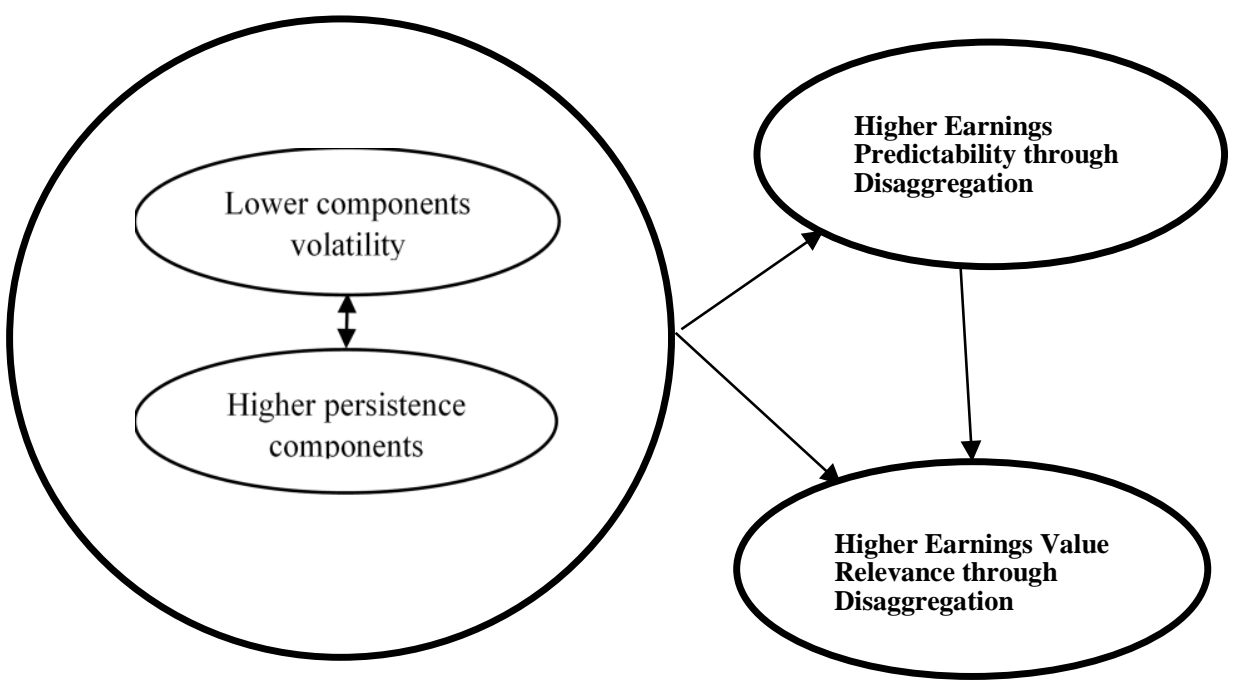

Figure 1. the relationships among qualities of earnings and their components

\section{Hypotheses}

If we consider the relationships among components volatility, their persistence and earnings predictability, we can expect that:

Hypothesis 1: Disaggregating earnings into their components improves earnings predictability.

Hypothesis 2: The lower the volatility component, the greater the earnings predictability through disaggregation.

Hypothesis 3: The greater the persistence component, the greater the earnings predictability through disaggregation.

If we consider the relationships among components volatility, their persistence and earnings predictability, we can expect that:

Hypothesis 4: Disaggregating earnings into their components improves earnings value relevance.

Hypothesis 5: The lower the component volatility, the greater the earnings value relevance through disaggregation.

Hypothesis 6: The greater the component persistence, the greater the earnings value relevance through disaggregation. 


\section{Research Methodology}

\section{Data and Sample Selection}

In order to collect data, we use available information on the Iranian RAHAVARD NOVIN databank and audited financial statements of selected firms listed in TSE. The sampling period is from 2005 through 2019. The criteria applied in selecting the sample are as follows:

- Investing, financial and service companies are excluded from the sample.

- Only companies with an Iranian 19 March fiscal year-end are included in the sample.

- The information on variables is available over the sampling period.

- The transaction interrupts for a firm's shares will not be more than 4 months.

- The firm shares have been transacted over the first 4 months of the selected years.

- The selected firms must be profitable during the sampling period.

By considering the above criteria, only 600 firm-year observations were eligible.

\section{Methods}

Dichev and Tang (2009) suggest that their analyses of the link between earnings volatility and its predictability are based on the following regression:

$\mathrm{E}_{\mathrm{t}}=\alpha+\beta^{*} \mathrm{E}_{\mathrm{t}-1}+\varepsilon$

By taking the variance on both sides, we have:

$\operatorname{Var}\left(\mathrm{E}_{\mathrm{t}}\right)=\beta^{2} * \operatorname{Var}\left(\mathrm{E}_{\mathrm{t}-1}\right)+\operatorname{Var}(\varepsilon)$

They assume that earnings variance is stationary over time. Therefore, re-arranging the equation yields:

$\operatorname{Var}(\varepsilon)=\operatorname{Var}(\mathrm{E}) *\left(1-\beta^{2}\right)$

$\operatorname{Var}(\mathrm{E})$ and $\operatorname{Var}(\varepsilon)$ are the proxies for earnings volatility and its predictability, respectively.

The last equation also describes the relation between earnings volatility and its predictability (Dichev \& Tang, 2009).

To compare the predictability of earnings and their components, two models were employed which were developed by Francis, LaFond, Olsson, and Schipper (2004) 
and Schiemann and Guenther (2013). Following Francis, LaFond, Olsson, and Schipper (2004) and Lipe (1990), earnings predictability is estimated as follows:

$E B E I_{i, t}=\beta_{0, i}+\beta_{1, i} E B E I_{i, t-1}+\varepsilon_{i, t}$

Where $\mathrm{EBEI}_{\mathrm{i}, \mathrm{t}}$ is net earnings of the company $\mathrm{i}$ in year $\mathrm{t}$.

Following Francis, LaFond, Olsson, and Schipper (2004) and Schiemann and Guenther (2013), earnings predictability is measured by the adjusted $\mathrm{R}^{2} \mathrm{~s}$. Adjusted coefficients of determination for model (4), the earnings model, are compared with those of the following regression model:

$E B E I_{i, t}=\gamma_{0, i}+\gamma_{1, i} E B E I_{i, t-1}+\gamma_{2, i} \operatorname{COMPONENT}_{i, t-1}+\xi_{i, t}$

Where COMPONENT $\mathrm{i}_{\mathrm{i}, \mathrm{-}-1}$ is earnings components in each line item for year $\mathrm{t}-1$.

In this research, all the main components of earnings examined by previous studies are used. These components are sales, cost of goods sold, employee expenses, depreciation, advertising, other selling, administrative and general (SGA) expenses, financial expenses, and income taxes. Both variables, EBEI and COMPONENT, are scaled by beginning total assets. Following Francis, LaFond, Olsson, and Schipper (2004) and Schiemann and Guenther (2013), separate regressions for each company are used over a roll of a ten-year window. For example, four regressions are carried out for a company with thirteen consecutive years: for years 4 to 13 , years 3 to 12 , years 2 to 11 and 1 to 10 . First, the adjusted $R^{2}$ s per firm is calculated. For analyses, the adjusted coefficients of determination for the earnings model and those of the component model are compared together for all ten-year window regressions ending in the specific year and difference of means test (t-test) for adjusted coefficients of determination for the earnings model and those of the component model is performed. If adjusted coefficients of determination for the components model are significantly higher than those of the earnings model (4), then decomposing earnings will cause an increase in earnings predictability.

To examine the effect of components persistence and their volatility on earnings predictability, the model developed by Etemadi, Azar, Sepasi and Babaie (2018) was used: 


$$
\begin{aligned}
R_{(5)}^{2}-R_{(4)}^{2}= & \alpha_{0}+\alpha_{1} \gamma_{2}^{2} \operatorname{VAR}\left(\operatorname{COM} P_{i . t-1}\right) \\
& +\alpha_{2} \gamma_{2}^{2}\left\{\frac{\operatorname{VAR}\left(\tau_{i . t}\right)}{\left(1-v_{i . t}^{2}\right)}\right\} \\
& +\alpha_{3} 2 \gamma_{1} \gamma_{2} \operatorname{COV}(E B E I . C O M P) \\
& +\alpha_{4} E A R P E R_{i . t}+\alpha_{5} \text { SIZE }_{i . t} \\
& +\alpha_{6} \text { MTBR }_{i . t}+\alpha_{7} \text { CFVAR }_{i . t} \\
& +\alpha_{8} \operatorname{SALVAR}_{i . t}+\alpha_{9} \text { OPCYC }_{i . t} \\
& +\alpha_{10} I_{N T I N T_{i . t}}+\alpha_{11} \text { INTDUM }_{i . t} \\
& +\alpha_{12} \text { CAPINT }_{i . t}+\omega_{i . t}
\end{aligned}
$$

Where,

EARPER $_{\mathrm{i}, \mathrm{t}}=$ Earnings persistence, that is coefficient $\beta_{1}$ in model (4),

$\mathrm{SIZE}_{\mathrm{i}, \mathrm{t}}=$ Firm size, measured asthe natural logarithms of assets,

$\mathrm{MTBR}_{\mathrm{i}, \mathrm{t}}=$ market-to-book ratio,

CFVAR $_{i, t}=$ Cash flow volatility, measured as the ratio of the standard deviation of cash flows from operations to beginning total assets,

SALVAR $_{i, t}=$ Sales volatility, measured as the ratio of the standard deviation of net sales revenues to beginning total assets,

$\mathrm{OPCYC}_{\mathrm{i}, \mathrm{t}}=$ firms' operating cycle, is measured as the sum of two numbers: a firm's days accounts receivable and days inventory,

INTINT $_{\mathrm{i}, t}=$ intensity of intangible assets, measured as the ratio of research and development expenses to net sales revenues,

INTDUM $_{\mathrm{i}, \mathrm{t}}=\mathrm{A}$ dummy variable that equals 1 , if research and development expenses are not presented in financial statements, and 0 otherwise,

CAPINT $_{i, t}=$ Capital intensity, measured as the ratio of tangible assets at net book value to beginning total assets.

Now, it is time to consider the relationships among components volatility, their persistence and earnings value relevance. To compare the value relevance of earnings and their components, the two models developed by Francis, LaFond, Olsson, and Schipper(2004), Chen and Wang (2004) and Schiemann and Guenther (2013) are used. Earnings value relevance is estimated as follows: 
$R E T_{i, t}=\delta_{0, i}+\delta_{1, i} E A R N_{i, t-1}+\delta_{2, i} \Delta E A R N_{i, t}+\rho_{i, t}$

Where $\mathrm{RET}_{\mathrm{i}, \mathrm{t}}$ is the returns for 16-month ending 4 months after the end of the year. Following Francis, LaFond, Olsson, and Schipper (2004) and Schiemann and Guenther (2013), earnings value relevance is measured based on the adjusted $\mathrm{R}^{2}$ s. Adjusted coefficients of determination for model (7), the earnings model, are compared with those of the following regression:

$$
\begin{gathered}
R E T_{i, t}=\emptyset_{0, i}+\emptyset_{1, i} E A R N_{i, t-1}+\emptyset_{2, i} \Delta E A R N_{i, t}+\emptyset_{3, i} \operatorname{COMPONENT}_{i, t-1} \\
+\emptyset_{4, i} \Delta \operatorname{COMPONENT_{i,t}}+\psi_{i, t}
\end{gathered}
$$

Where EARN is measured as net earnings. These variables are standardized with the firm's beginning total assets. As discussed earlier, the regressions were run and the difference of means test (t-test)was performed for adjusted coefficients of determination for the earnings model and those of the component model. If adjusted coefficients of determination for model (8) are significantly higher than those of model (7), then components disaggregation will cause an increase in earnings value relevance. To construct a model to examine the effect of components persistence and their volatility on earnings value relevance, the methods used by Dichev and Tang (2009) and developed by Etemadi Azar, Sepasi and Babaie,(2018) were followed. Taking the variance from both sides of models (7) and (8), subtracting the error terms, substituting components volatility with their persistence yields:

$$
\begin{aligned}
& R_{(15)}^{2}-R_{(14)}^{2}=\mu_{0}+\mu_{1} \phi_{3}^{2} \operatorname{VAR}\left(\operatorname{COM} P_{i . t-1}\right)+\mu_{2} \phi_{3}^{2} \frac{\operatorname{VAR}\left(\tau_{j, t}\right)}{\left(1-v_{1, j}^{2}\right)} \\
& +\mu_{3} \phi_{4}^{2} \operatorname{VAR}\left(\triangle C O M P_{i . t}\right) \\
& +\mu_{4} 2 \phi_{1} \phi_{3} \operatorname{COV}\left(E A R N_{i . t-1} \cdot \operatorname{COM} P_{i . t-1}\right) \\
& +\mu_{5} 2 \phi_{1} \phi_{4} \operatorname{COV}\left(E A R N_{i . t-1} \cdot \triangle \operatorname{COMP}_{i . t}\right) \\
& +\mu_{6} 2 \phi_{2} \phi_{3} \operatorname{COV}\left(\Delta E A R N_{i . t} \cdot \operatorname{COM} P_{i . t-1}\right) \\
& +\mu_{7} 2 \phi_{2} \phi_{4} \operatorname{COV}\left(\Delta E A R N_{i . t} \cdot \Delta C O M P_{i . t}\right) \\
& +\mu_{8} 2 \phi_{3} \phi_{4} \operatorname{COV}\left(\operatorname{COMP}_{i . t-1} \cdot \Delta \operatorname{COM} P_{i . t}\right) \\
& +\mu_{9} E_{A R P E R_{i . t}}+\mu_{10} \operatorname{SIZE}_{i . t}+\mu_{11} \text { MTBR }_{i . t} \\
& +\mu_{12} C F V A R_{i . t}+\mu_{13} S A L V A R_{i . t}+\mu_{14} O P C Y C_{i . t} \\
& +\mu_{15} I_{N T I N T} . t+\mu_{16} I_{N T D U M} . t \\
& +\mu_{17} \text { CAPINT }_{i . t}+\chi_{i . t}
\end{aligned}
$$




\section{Research Findings}

\section{Descriptive statistics}

First, we take a look at the descriptive statistics. Table 1 displays a steady increase in the size of the selected firms from 2014 to 2019 and over the first three years of the study period. There is a decreasing trend in the standard deviation of variable SIZE. The ratio of market to book value (MTBR) has experienced a significant decrease from 3.05 in 2014 to 1.98 in 2016 for the selected firms. The reason for this change is that the current value of the selected firms has significantly decreased during the study period, so the nominator of the ratio has decreased. We can see an increase in variable SALVAR during the period. Furthermore, there is an increase and then a decrease in variable OPCYC. The reason for the increase in the variable could be the change in the firms' credit policies and their inability to collect their receivables as quickly as they used to be. In addition, importing raw materials can be more difficult than it used to be. There had been several sanctions against Iran. As the economic sanctions were lifted in 2015, Iran's economy received a boost that might cause these fluctuations in sales and other variables.

\section{Predictability tests}

To test the first hypothesis, the regressions in models (4) and (5) are run to obtain the firm's adjusted $\mathrm{R}^{2} \mathrm{~s}$ over a roll of a ten-year window. Next, the adjusted $\mathrm{R}^{2} \mathrm{~s}$ of the model (4) and those of the model (5) for all components are compared with a roll of the ten-year window ending in years 2014 (from 2005 to 2014), 2015, 2016, 2017, 2018 and 2019. Finally, the difference of means test (t-test) for the adjusted $\mathrm{R}^{2} \mathrm{~s}$ of the model (4) and those of model (5). Tables 2 and 3 show the results of t-tests for the adjusted $R^{2} s$ in models (4) and (5). In the tables, we can see a decrease in adjusted $\mathrm{R}^{2}$ sand then an increasing trend in those amounts for each component in the model (5) and earnings in the model (4). But if we compare the amounts for each year, we can mostly see higher $\mathrm{R}^{2} \mathrm{~s}$ for model (5). The results of the tests through performing difference of means test (t-test) for the adjusted $\mathrm{R}^{2} \mathrm{~s}$ of the model (4) and those of model (5) show that the differences are significant between model (5) (for sales, employee expenses, other SGA expenses and income taxes) and model (4). Afterwards, we test the second and third hypotheses using these components. 
Table 1. descriptive statistics for variables used in the models

\begin{tabular}{|c|c|c|c|c|c|c|c|c|c|}
\hline Year & \multicolumn{3}{|c|}{ SIZE } & \multicolumn{3}{|c|}{ MTBR } & \multicolumn{3}{|c|}{ SALVAR } \\
\hline & Mean & Median & Std & Mean & Median & Std & Mean & Median & Std \\
\hline 2014 & 14.29 & 14.19 & 1.30 & 3.05 & 2.65 & 2.92 & 0.05 & 0.03 & 0.06 \\
\hline 2015 & 14.46 & 14.44 & 1.29 & 1.98 & 1.31 & 1.89 & 0.06 & 0.03 & 0.09 \\
\hline 2016 & 14.56 & 14.49 & 1.27 & 2.78 & 2.22 & 1.70 & 0.06 & 0.03 & 0.11 \\
\hline 2017 & 14.69 & 14.61 & 1.28 & 2.93 & 2.37 & 1.82 & 0.07 & 0.03 & 0.11 \\
\hline 2018 & 14.81 & 14.69 & 1.30 & 2.56 & 2.27 & 2.09 & 0.05 & 0.03 & 0.07 \\
\hline \multirow[t]{2}{*}{2019} & 15.08 & 15.06 & 1.33 & 2.78 & 2.57 & 1.16 & 0.07 & 0.03 & 0.10 \\
\hline & \multicolumn{3}{|c|}{ CAPINT } & \multicolumn{3}{|c|}{ CFVAR } & \multicolumn{3}{|c|}{ INTINT } \\
\hline 2014 & 0.21 & 0.17 & 0.17 & 0.01 & 0.01 & 0.02 & 0.002 & - & 0.004 \\
\hline 2015 & 0.23 & 0.17 & 0.17 & 0.01 & 0.01 & 0.02 & 0.002 & - & 0.004 \\
\hline 2016 & 0.24 & 0.19 & 0.16 & 0.01 & 0.01 & 0.02 & 0.001 & - & 0.004 \\
\hline 2017 & 0.23 & 0.19 & 0.16 & 0.01 & 0.01 & 0.02 & 0.001 & - & 0.004 \\
\hline 2018 & 0.22 & 0.18 & 0.14 & 0.01 & 0.01 & 0.01 & 0.002 & - & 0.004 \\
\hline \multirow[t]{2}{*}{2019} & 0.19 & 0.15 & 0.13 & 0.01 & 0.01 & 0.02 & 0.001 & - & 0.003 \\
\hline & \multicolumn{3}{|c|}{ OPCYC } & \multicolumn{3}{|c|}{ EARPER } & \multicolumn{3}{|c|}{ INTDUM } \\
\hline 2014 & 335 & 292 & 219 & 0.16 & - & 0.30 & 0.35 & - & 0.48 \\
\hline 2015 & 402 & 344 & 309 & 0.04 & - & 0.28 & 0.35 & - & 0.48 \\
\hline 2016 & 445 & 436 & 293 & 0.03 & - & 0.23 & 0.30 & - & 0.46 \\
\hline 2017 & 335 & 312 & 184 & 0.10 & - & 0.30 & 0.30 & - & 0.46 \\
\hline 2018 & 381 & 372 & 214 & 0.10 & - & 0.25 & 0.38 & - & 0.48 \\
\hline 2019 & 356 & 323 & 193 & 0.16 & - & 0.29 & 0.38 & - & 0.48 \\
\hline
\end{tabular}

To obtain variable $\operatorname{VAR}\left(\tau_{i, t}\right), v_{0}$ and $v_{1}$ are calculated in the model (10) for components through running the regressions over a roll of the ten-year window. Using these coefficients, the predicted sales, employee expenses, other SGA expenses, and income taxes are calculated for those years ending in the aforementioned ten-year windows. Then, the predicted and actual components for those years are calculated. The difference between the actual and predicted amounts results in variable $\tau_{\mathrm{i}, \mathrm{t}}$. And finally, we take the variance of this variable.

COMPONENT $_{i, t}=v_{0, i}+v_{1, i}$ COMPONENT $_{i, t-1}+\tau_{i, t}$

The coefficient of this model $\left(v_{1, i}\right)$ is the proxy for components persistence. 
Table 2. the results of t-tests for the difference between adjusted $R^{2} s$ of Model 4 and those of Model 5 (sales, advertising, cost of goods sold and depreciation)

\begin{tabular}{|c|c|c|c|c|c|c|c|c|}
\hline & \multicolumn{2}{|c|}{ Sales } & \multicolumn{2}{|c|}{ Advertising } & \multicolumn{2}{|c|}{$\begin{array}{l}\text { Cost of goods } \\
\text { sold }\end{array}$} & \multicolumn{2}{|c|}{ Depreciation } \\
\hline خ্خ & 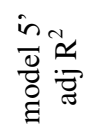 & 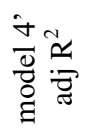 & 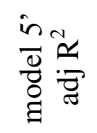 & 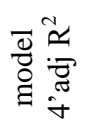 & 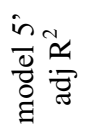 & 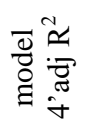 & 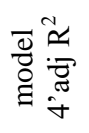 & 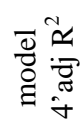 \\
\hline & & & & & & & & \\
\hline 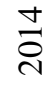 & $\stackrel{n}{0}$ & $\stackrel{0}{0}$ & $\frac{1}{0}$ & $\stackrel{0}{0}$ & $\stackrel{m}{0}$ & $\stackrel{0}{0}$ & $=$ & $\stackrel{0}{0}$ \\
\hline$\frac{n}{\stackrel{2}{c}}$ & $\stackrel{0}{\circ}$ & ô. & $\stackrel{n}{o}$ & ¿̊. & O̊. & o. & ¿̊. & ¿̊. \\
\hline 윰 & 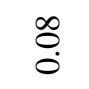 & $\stackrel{n}{0}$ & $\stackrel{1}{\circ}$ & $\stackrel{2}{0}$ & $\stackrel{0}{0}$ & $\stackrel{2}{0}$ & $\stackrel{8}{0}$ & $\stackrel{n}{0}$ \\
\hline อิ & $\stackrel{ \pm}{0}$ & oे & $\frac{\pi}{0}$ & $\stackrel{8}{0}$ & $\overline{0}$ & oे. & $\stackrel{m}{0}$ & $\stackrel{8}{0}$ \\
\hline$\stackrel{\infty}{\stackrel{\sim}{\circ}}$ & $\stackrel{m}{0}$ & 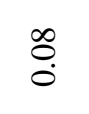 & $\stackrel{m}{0}$ & $\begin{array}{l}\infty \\
0 \\
0\end{array}$ & $\stackrel{5}{\stackrel{3}{*}}$ & $\begin{array}{l}\text { 恶 } \\
\stackrel{0}{0} \\
0\end{array}$ & $\stackrel{1}{0}$ & $\stackrel{\infty}{\circ}$ \\
\hline हें & $\frac{m}{0}$ & $\begin{array}{l}\circ \\
0 \\
0\end{array}$ & $\overline{0}$ & $\frac{0}{0}$ & $\overline{0}$ & $\stackrel{0}{0}$ & $\stackrel{1}{0}$ & $\stackrel{0}{0}$ \\
\hline$\stackrel{\widetilde{J}}{0}$ & $\stackrel{\text { * }}{\stackrel{2}{O}}$ & $\stackrel{\text { * }}{\stackrel{2}{\circ}}$ & $\frac{0}{3}$ & $\stackrel{\infty}{8}$ & $=$ & $\stackrel{\infty}{8}$ & $\stackrel{0}{0}$ & $\stackrel{\infty}{\varrho}$ \\
\hline & & & & & & & & \\
\hline
\end{tabular}

Finally, we test the second and third hypotheses. The results are presented in tables 4 and 5 . In all of the regressions, the variables with autocorrelation with other independent variables are removed. In table 4 , there is a significant relationship between the dependent variable (differential $R^{2} s$ ) and sales persistence (variable $\emptyset_{3}^{2} \operatorname{VAR}\left(\tau_{i, t}\right) /\left(1-v_{1, j}^{2}\right)$. The result is consistent with hypothesis

3. It means that when components persistence increases, the differential 
predictability increases and therefore, it would be better to use the component model.

Table 3. the result of t-tests for the difference between adjusted $\mathrm{R}^{2} \mathrm{~s}$ of Model 4 and those of Model 5

\begin{tabular}{|c|c|c|c|c|c|c|c|c|}
\hline & \multicolumn{2}{|c|}{$\begin{array}{c}\text { Other SGA } \\
\text { expenses }\end{array}$} & \multicolumn{2}{|c|}{ Employee expenses } & \multicolumn{2}{|c|}{$\begin{array}{l}\text { Financial } \\
\text { expenses }\end{array}$} & \multicolumn{2}{|c|}{ Income taxes } \\
\hline 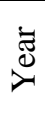 & 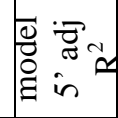 & 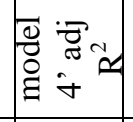 & 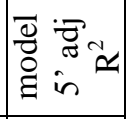 & 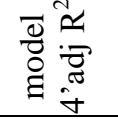 & 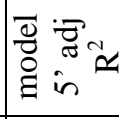 & 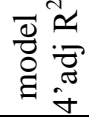 & 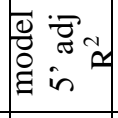 & 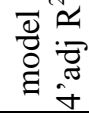 \\
\hline$\stackrel{ \pm}{\stackrel{d}{~}}$ & $\frac{1}{0}$ & $\stackrel{0}{\circ}$ & $\frac{1}{0}$ & $\stackrel{0}{\circ}$ & $\frac{m}{0}$ & $\stackrel{1}{0}$ & $\frac{\infty}{0}$ & $\stackrel{0}{0}$ \\
\hline$\stackrel{n}{\stackrel{2}{c}}$ & $\stackrel{0}{0}$ & ọ. & $\stackrel{8}{0}$ & Sọ. & $\stackrel{5}{0}$ & $\stackrel{5}{0}$ & $\stackrel{m}{0}$ & $\stackrel{1}{0}$ \\
\hline$\stackrel{0}{\circ}$ & $\stackrel{0}{0}$ & $\stackrel{2}{0}$ & $\stackrel{\infty}{\circ}$ & $\stackrel{n}{0}$ & $\stackrel{5}{0}$ & $\stackrel{?}{\circ}$ & $=$ & $\stackrel{n}{0}$ \\
\hline 홍 & $\stackrel{ \pm}{ \pm}$ & $\stackrel{\circ}{0}$ & $\stackrel{m}{0}$ & $\stackrel{\circ}{0}$ & $=$ & $\stackrel{\circ}{\circ}$ & $\stackrel{ \pm}{0}$ & $\stackrel{8}{0}$ \\
\hline$\stackrel{\infty}{\check{d}}$ & $\frac{0}{0}$ & $\stackrel{\infty}{\circ} \stackrel{0}{0}$ & $\frac{n}{0}$ & $\stackrel{\infty}{0}$ & $\overrightarrow{0}$ & $\stackrel{\infty}{\stackrel{0}{0}} \stackrel{0}{0}$ & $\frac{ \pm}{0}$ & $\stackrel{\infty}{\stackrel{0}{0}}$ \\
\hline$\frac{\curvearrowright}{\stackrel{\nu}{~}}$ & $\stackrel{1}{\circ}$ & $\stackrel{0}{0}$ & $\stackrel{m}{0}$ & $\stackrel{0}{\circ}$ & $\stackrel{2}{0}$ & $\stackrel{\circ}{\circ}$ & $\frac{n}{0}$ & $\stackrel{\circ}{0}$ \\
\hline 氶 & $\stackrel{3}{0}$ & $\stackrel{\text { *. }}{\stackrel{*}{*}}$ & $\stackrel{\frac{*}{*}}{\frac{3}{0}}$ & $\stackrel{\text { *. }}{\stackrel{2}{\infty}}$ & $\stackrel{\circ}{\circ}$ & $\stackrel{\infty}{\rho}$ & $\stackrel{*}{ \pm}$ & $\stackrel{*}{\infty}$ \\
\hline
\end{tabular}

Table 4. coefficients- Sales and Earnings

\begin{tabular}{|c|c|c|c|c|c|c|c|}
\hline \multirow[t]{2}{*}{ Model } & \multicolumn{2}{|c|}{$\begin{array}{l}\text { Unstandardized } \\
\text { Coefficients }\end{array}$} & \multirow{2}{*}{$\begin{array}{c}\text { Standardized } \\
\text { Coefficients }\end{array}$} & \multirow[t]{2}{*}{$\mathrm{t}$} & \multirow[t]{2}{*}{ Sig. } & \multicolumn{2}{|c|}{$\begin{array}{l}\text { Collinearity } \\
\text { Statistics }\end{array}$} \\
\hline & \begin{tabular}{l|l}
$\mathrm{B}$ & \\
\end{tabular} & Std. Error & & & & Tol & VIF \\
\hline (Constant) & .115 & .106 & & 1.08 & .282 & & \\
\hline$\gamma_{2}^{2}\left\{\operatorname{VAR}\left(\tau_{\mathrm{i}, \mathrm{t}-1}\right) /\left(1-v_{\mathrm{i}, \mathrm{t}}^{2}\right)\right\}$ & .767 & .167 & .298 & 4.60 & .000 & .857 & 1.17 \\
\hline $2 \gamma_{1} \gamma_{2} \operatorname{COV}(E B E I . C O M P)$ & -3.273 & 1.578 & -.131 & -2.07 & .439 & 901 & 1.11 \\
\hline EARPER & -.046 & .033 & -.091 & -1.40 & .162 & .852 & 1.17 \\
\hline SIZE & -.006 & .007 & -.055 & -.88 & .381 & .927 & 1.08 \\
\hline MTBR & -.008 & .005 & -.108 & -1.68 & .095 & .861 & 1.16 \\
\hline CFVAR & 1.274 & .525 & .150 & 2.43 & .016 & .948 & 1.06 \\
\hline SALVAR & .097 & .104 & .061 & .94 & .349 & .840 & 1.19 \\
\hline OPSIS & $4.3 \mathrm{E}-5$ & .000 & .073 & 1.11 & .267 & .839 & 1.19 \\
\hline INTINT & -1.412 & 2.951 & -.036 & -.48 & .633 & .653 & 1.53 \\
\hline INTDUM & -.018 & .024 & -.059 & -.74 & .461 & .558 & 1.79 \\
\hline
\end{tabular}


Iranian Journal of Finance, 2021, Vol. 5, No. 4 (Babaie, S.)

\begin{tabular}{||c|c|c|c|c|c|c|c|}
\hline CAPINT & -.015 & .062 & -.016 & -.24 & .809 & .781 & 1.28 \\
\hline \multicolumn{6}{|c|}{$\mathrm{R}=0 / 42, \mathrm{R}$ Square $=0 / 179, \mathrm{~A}-\mathrm{R}^{2}=0 / 139$, Sig. $=0 / 00$, Durbin Watson $=1 / 967$} & & \\
\hline
\end{tabular}

The results of tests for other components are presented in table 5 .

Table 5. the relationship among incremental earnings predictability and the qualities of its components

\begin{tabular}{|c|c|c|}
\hline component & Volatility & Persistence \\
\hline Employee Expenses & + & \\
\hline SGA Expenses & + & + \\
\hline Income Taxes & + & + \\
\hline
\end{tabular}

Persistence components and their volatility play an important role in improving earnings predictability using the component model. Increasing income components persistence and their volatility results in improving earnings predictability using the component model.

\section{Value relevance tests}

In this section, all the tests pertaining to the value relevance models are briefly presented. Similar to the previous section, the results of testing hypothesis 4 are presented in table6(annual tests not presented). In the table, the results show that only employee expenses improve earnings value relevance. Finally, the results of testing the fifth and sixth hypotheses are presented in table 7 . In table 7 , there is a significant and positive relationship between the dependent variable (incremental $R^{2}$ ) and employee expenses volatility (variable $\gamma_{2}^{2}$ VAR $\left.\left(\mathrm{COMP}_{\mathrm{i}, \mathrm{t}-1}\right)\right)$. The result is not consistent with hypothesis 5 . It means that if employee expenses volatility increases, earnings value relevance using the component model increases, and it would be better to use the component model.

Table 6. the results of t-tests for the difference between adjusted $\mathrm{R}^{2}$ of Model 7 and that of Model 8

\begin{tabular}{|c|c|c|c|c|c|c|c|c|}
\hline & \multicolumn{2}{|c|}{ Sales } & \multicolumn{2}{|c|}{ Advertising } & \multicolumn{2}{|c|}{$\begin{array}{c}\text { Cost of goods } \\
\text { sold }\end{array}$} & \multicolumn{2}{|c|}{ Depreciation } \\
\hline$\stackrel{\Xi}{\circlearrowright}$ & 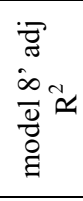 & 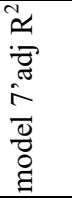 & 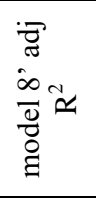 & 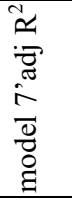 & 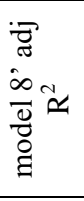 & 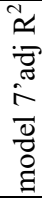 & 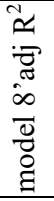 & 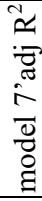 \\
\hline 䒿 & $\stackrel{\infty}{\sim}$ & గొ & กै & ?ొ & ़ֻ & ֶֻ. & $\tilde{n}$ & ?ై \\
\hline & \multicolumn{2}{|c|}{ Other SGA expenses } & \multicolumn{2}{|c|}{ Employee expenses } & \multicolumn{2}{|c|}{$\begin{array}{l}\text { Financial } \\
\text { expenses }\end{array}$} & \multicolumn{2}{|c|}{ Income taxes } \\
\hline
\end{tabular}




\begin{tabular}{|c|c|c|c|c|c|c|c|c|}
\hline 吾 & $\stackrel{n}{n}$ & $\begin{array}{l}0 \\
\text { లె }\end{array}$ & $\stackrel{\text { \% }}{\stackrel{*}{*}}$ & مْ & ֻి & 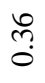 & $\stackrel{m}{0}$ & $\begin{array}{l}\text { ?ִ } \\
\text { ?ִ }\end{array}$ \\
\hline
\end{tabular}

\section{Mediation tests}

The mediation role of earnings predictability is included in the last part of examining our conceptual model in figure 1 . This role is considered when we examine the effect of employee expenses volatility on earnings value relevance. The volatility of employee expenses positively affects earnings predictability and its value relevance using the component model. So, we investigate the mediating role of earnings predictability in the relationship between employee expenses volatility and earnings value relevance. To this end, regression and Sobel tests are used (tables not presented). The results of these tests show that earnings predictability does not have a mediating role, and employee expenses volatility has a direct effect on both earnings predictability and its value relevance. Now, we can show our previously conceptualized model in figure 2 .

Table 7. Coefficients- Employee Expenses and Earnings

\begin{tabular}{|c|c|c|c|c|c|c|c|c|}
\hline \multirow{2}{*}{ Model } & \multicolumn{2}{|c|}{ Unstand. Coeff. } & \multirow{2}{*}{\multicolumn{2}{|c|}{\begin{tabular}{|c} 
Stand. Coeff. \\
Beta
\end{tabular}}} & \multirow{2}{*}{$\mathrm{T}$} & \multicolumn{2}{|c|}{ Sig. } & \multirow{2}{*}{\begin{tabular}{|c}
$\begin{array}{c}\text { Collin. } \\
\text { Stat. }\end{array}$ \\
VIF
\end{tabular}} \\
\hline & B & Std. Errc & & & & \multicolumn{2}{|c|}{ Tol } & \\
\hline \multicolumn{2}{|c|}{ (Constant) } & \begin{tabular}{|l|l|}
.301 \\
\end{tabular} & .200 & & 1.506 & .133 & & \\
\hline \multicolumn{2}{|c|}{$\phi_{3}^{2} \operatorname{VAR}\left(\mathrm{COMP}_{\mathrm{i} . \mathrm{t}-1}\right)$} & $2.39 \mathrm{E}-5$ & .000 & .190 & 2.273 & .024 & .546 & 1.832 \\
\hline \multicolumn{2}{|c|}{$\varphi_{3}^{2} \operatorname{VAR}\left(\tau_{\mathrm{j}, \mathrm{t}}\right) /\left(1-\mathrm{v}_{\mathrm{j}, \mathrm{t}}^{2}\right)$} & $4.36 \mathrm{E}-7$ & .000 & .023 & .295 & .768 & .632 & 1.583 \\
\hline \multicolumn{2}{|c|}{$2 \phi_{1} \phi_{3} \operatorname{COV}\left(\mathrm{EARN}_{\mathrm{i} . \mathrm{t}-1} \cdot \mathrm{COMP}_{\mathrm{i} . \mathrm{t}-1}\right)$} & $-4.9 \mathrm{E}-5$ & .000 & -.176 & -2.376 & .418 & .690 & 1.449 \\
\hline \multicolumn{2}{|c|}{$2 \phi_{2} \phi_{3} \operatorname{COV}\left(\Delta \mathrm{EARN}_{\mathrm{i} . \mathrm{t}} \cdot \mathrm{COMP}_{\mathrm{i} . \mathrm{t}-1}\right)$} & $-1.2 \mathrm{E}-5$ & .000 & -.054 & -.843 & .400 & 920 & 1.087 \\
\hline \multicolumn{2}{|c|}{ EARPER } & -.087 & .061 & -.094 & -1.420 & .157 & .860 & 1.163 \\
\hline \multicolumn{2}{|c|}{ SIZE } & -.020 & .013 & -.100 & -1.536 & .126 & .894 & 1.119 \\
\hline \multicolumn{2}{|c|}{ MTBR } & -.001 & .009 & -.008 & -.117 & .907 & .841 & 1.188 \\
\hline \multicolumn{2}{|c|}{ CFVAR } & .125 & .984 & .008 & .127 & .899 & .920 & 1.087 \\
\hline \multicolumn{2}{|c|}{ SALVAR } & .355 & .191 & .125 & 1.856 & .065 & .840 & 1.190 \\
\hline \multicolumn{2}{|c|}{ OPSIS } & $4.47 \mathrm{E}-5$ & .000 & .042 & .616 & .539 & .808 & 1.238 \\
\hline \multicolumn{2}{|c|}{ INTINT } & \begin{tabular}{|l|}
-6.626 \\
\end{tabular} & 5.455 & -.093 & -1.215 & .226 & .652 & 1.535 \\
\hline \multicolumn{2}{|c|}{ INTDUM } & -.004 & .044 & -.008 & -.099 & .922 & .568 & 1.761 \\
\hline \multicolumn{2}{|c|}{ CAPINT } & .128 & .116 & \begin{tabular}{|l|}
.077 \\
\end{tabular} & 1.103 & .271 & .774 & 1.292 \\
\hline
\end{tabular}




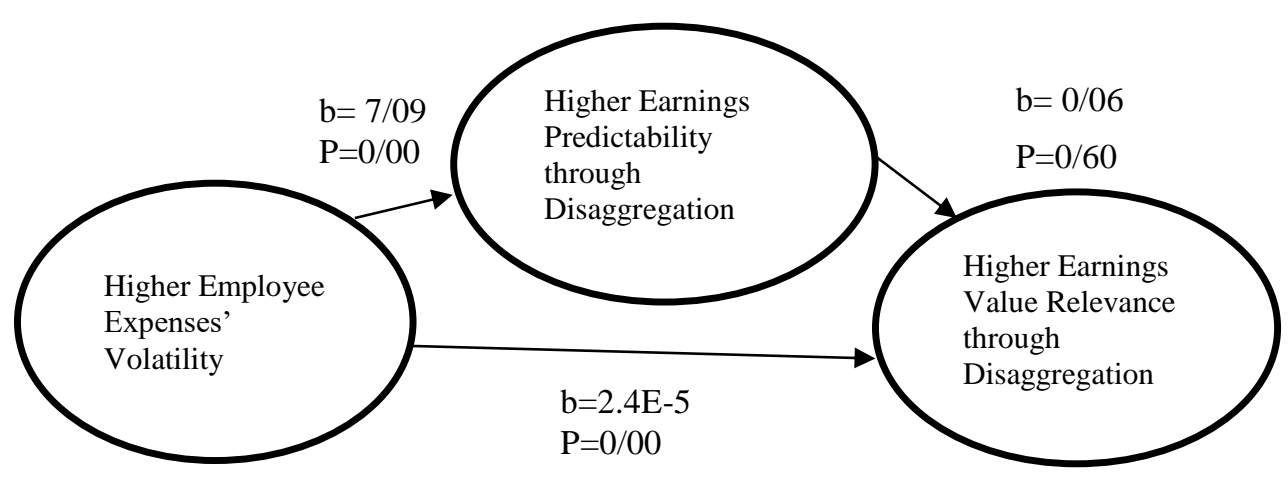

Figure 2. the relationships among qualities of earnings and employee expenses

\section{Conclusion}

Previous studies investigated the predictability and value relevance of financial statements. Bratten (2009) argues that the value relevance and persistence of earnings has declined over the past period. In this setting, looking for other proxies is inevitable. Beisland (2009) argues that the value relevance of book equity is generally stronger than that of earnings. However, the value relevance of measures reported in balance sheets is affected by the valuation principles used for balance sheet components. On the other hand, the proponents of the relevancy and predictability of earnings argue that information from the components improves the value relevance of earnings. In this research, we examined the ability of the components to compensate for the decrease in the information content of earnings and considered the main components used in the previous studies. The results of tests for the first hypothesis show that earnings disaggregation into its components (sales, employee expenses, other SGA expenses and income taxes) can improve earnings predictability. The result of tests for the fourth hypothesis shows that earnings disaggregation into its components (employee expenses) can improve earnings value relevance. As we discussed before, the results of previous studies show that when the volatility of earnings increases and the correspondent persistence decreases, past earnings is not a good predictor of future earnings. So, disaggregated information from income statements can improve the ability of users to predict future earnings. We examined several variables causing the improvement in 
predictability and value relevance of income statement information. Among other things, two of them (persistence and volatility) attracted our interest to test the second, third, fifth and sixth hypotheses. The results show that the disaggregation of earnings into its components will improve the ability of users to predict subsequent earnings in case of an increase in the volatility of employee expenses, other SGA expenses, and income taxes. Increasing the persistence of sales, other SGA expenses and income taxes can also improve the earnings predictability through disaggregation. The results of value relevance tests show that in case of an increase in the volatility of employee expenses, it would be better to use earnings and their components in order to improve value relevance. In general, higher volatility of such big components as employee expenses may persuade us to use the component model. It means that when the volatility of earnings components is low, there are fewer fluctuations in net earnings and we can use net earnings for making predictions. But as the volatility of components, such as employee expenses, increases, disaggregation can improve earnings predictability and value relevance. The findings can provide useful information for investors, management, standard setters and other users. Investors can consider the information content of earnings components in their decision models to make better investments and other decisions. In addition, the findings suggest standard-setters can work more on those standards that can improve the disclosure of earnings components we studied.

\section{Suggestions}

The results of the current study can be used in different companies according to the importance of income statement items. For example, a company may be capital-intensive, meaning that machinery accounts for a larger share of the production process. In this case, employee expenses are a small item in income statements, and the results of the study about the impact of quality measures of employee expenses on value relevance and profitability are not true for these firms. In labor-intensive companies, human capital plays a significant role in the company's production process and core operations, and due to the creation of added value by human resources, employee expenditures can contribute to current and future profitability.

The results also show that income statement items can contain information about future performance. For example, employee expenses can contain a message about future profitability, so the results of the current expenses will be worthwhile in the not-too-distant future. According to Schiemann and Geunther (2013), such expenses can contain an investment 
element that is reflected in income statements, but as an asset, they can have future economic benefits. Thus, although management may be tempted to reduce expenses by implementing real and accrual earnings management to improve the performance and value of the firm, the findings can change the perception and purpose of corporate management to do so.

Given the presentation of items in financial statements, it seems that it is necessary to formulate how to present and disclose some information in the accompanying notes, since companies in recent years have reduced the details of production and non-production costs, and summarized cost information in the form of other cost headings. Apart from that, there is no consistency in providing information on certain expenses in the current year and revised amounts in the following years, and the information of some activities mentioned in Management's Discussion and Analysis is hidden in other expenses. Expenditures such as human resources have always been debated. Some believe that human resources should be valued and shown in the balance sheet. The companies' practice has been to report the cost of human resources in the income statement, especially, in the accompanying notes and Management's Discussion and Analysis. Monetary information is provided in detail in the Production and Non-Production Costs section, and non-monetary information is provided in Management's Discussion and Analysis. A better interpretation of costs may require the presentation of single amounts in accompanying notes, which are currently available separately in the manufacturing and non-manufacturing sectors, and often without final aggregation in those sections. This is also true for the cost of depreciation and research and development costs. Advertising and marketing expenses were also among the items that did not affect the value relevance and profitability. Companies, in order to compete, avoid providing transparent amounts of research and development or advertising and marketing expenditures in financial statements. Generally, the "other expenses" item can include amounts for such expenses as Management's Discussion and Analysis and the amounts revised in different years show that these expenses are not classified under related headings in the current year or the following years. Therefore, reflecting the amounts related to these expenses in some years and keeping them hidden in other headings for other years can reduce their information content. Therefore, it is necessary for standard-setters to develop appropriate procedures for disclosing cost and revenue information in financial statements.

In future studies, other measures of earnings quality (timeliness, quality of accruals, conditional conservatism) can be considered in improving the information content of income statement information. Investigating the role of 
line items together with their components and net earnings in improving the information content of income statements would be an interesting topic to be studied.

Many studies have shown that accounting and taxable profits are always different, and in most cases, the company pays a different amount than what is reported in its books. The amount reflected in the income statement is the Pro forma profits tax, but most of the time the company pays a different amount of income tax after receiving a notice of assessment. Some studies suggest that the differences between accounting and taxable profits add to predictability. These differences can be used in future research studies.

Financial information was not available for some firms listed on Tehran Stock Exchange. So, these firms were excluded from the study sample. Furthermore, as we used the elimination method in sample selection, there can be some constraints on generalizing the study findings to other settings.

\section{References}

Ahmadi, A.,\&Bouri, A. (2018). The Accounting Value Relevance of Earnings and Book Value: Tunisian Banks and Financial Institutions. International Journal of Law and Management, 60(2):342-354.

Beest, F. V., Braam, G., \& Boelens, S. (2009). Quality of Financial Reporting: Measuring Qualitative Characteristics. Radboud University. Retrieved fromhttp://www.dphu.org/uploads/attachements/books/books_3437_0.pdf.

Beisland, L. A. (2009).A Review of the Value Relevance Literature.The Open Business Journal, 2(1): 7-27.

Bratten, B. M. (2009). Analysts' Use of Earnings Components in Predicting Future Earnings. The University of Texas at Austin. Retrieved fromhttp://citeseerx.ist.psu.edu/viewdoc/download?doi=10.1.1.428.1508\&rep=r ep1\&type=pdf.

Burke, Q. L., Warfield, T. D., \&Wieland, M. M. (2020). Value Relevance of Disaggregated Information: An Examination of the Rate and Volume Analysis of Bank Net Interest Income. Accounting Horrizons, 34(1):19-43.

Chandra, U., \& Ro, B. T. (2008). The Role of Revenue in Firm Valuation. Accounting Horizons, 22(2):199-222.

Chen, S., \& Wang, Y. (2004). Evidence from China on the Value Relevance of Operating Income vs. Below-the-line Items. The International Journal of Accounting, 39(4): 339-364. 
Clubb, C., \& Wu, G. (2014). Earnings Volatility and Earnings Prediction: Analysis and UK Evidence. Journal of Business, Finance and Accounting, 41(1-2): 5372.

Dichev, L. D., \& Tang, W. W. (2009). Earnings Volatility and Earnings Predictability. Journal of Accounting and Economics, 47(1-2):160-181.

Etemadi, H., Azar, A., Sepasi, S.\& Babaie, S. (2018). The Incremental Effect of Earnings Components' Volatility and their Persistence on Earnings Predictability. Asset Management and Financing, 21(2):159-182. (in Persian)

Francis, J., LaFond, R., Olsson, M., \&Schipper, K. (2004). Costs of Equity and EarningsAttributes. Accounting Review, 79(4): 967-1010.

Hashemi, S., Amiri, H., \&Moinghafghazi, R. (2013). The Effects of Cost of Capital on the Relationship between Earnings and Stock Returns. Iranian Journal of Empirical Studies in Financial Accounting, 38(2013), 91-117. (in Persian)

Hosseinzadeh, A. H., \&Ahmadinia, S. (2009). Examining the Relevancy Degree of Accounting Earnings' Components and Operating Cash Flows to Stock Returns. Iranian Journal of financial Accounting, 3(2009):107-130. (in Persian)

Jafari, M. (2009). Information Content of Earnings Components with the Price and Returns of Companies Listed in TSE. Master's Thesis, Islamic Azad University, Marvdasht Branch. (in Persian)

Krishnan, G. V., \& Parsons, L. M. (2008). Getting to the Bottom Line: An Exploration of Gender and Earnings Quality. Journal of Business Ethics, 78(1): 65-76.

Lipe, R. (1986). The Information Contained in the Components of Earnings. Journal of Accounting Research, 24(1):37 - 64.

Lipe, R. (1990). The Relation between Stock Returns and Accounting Earnings Given Alternative Information. The Accounting Review, 65(1):49-71.

Ohlson J. A., \&Penman S. H. (1992). Disaggregated Accounting Data as Explanatory Variables for Returns. Journal of Accounting, Auditing and Finance, 7(4):553-573.

Pronobis, P., Schwetzler, B., Sperling, M. O., \& Zulch, H. (2008). The Development of Earnings Quality in Germany and its Implication for Further Research: A Quantitative Empirical Analysis of German Listed Companies Between 1997 and 2006. The 2009 Annual Conference of the European Accounting Association. Retrieved from:https://papers.ssrn.com/sol3/papers2.cfm?abstract_id=1266589.

Schiemann, F., \& Geunther, T. (2013). Earnings Predictability, Value Relevance, and Employee Expenses. The International Journal of Accounting, 48(2): 149-172. 
Shahryari, A., Barzideh, F., \& Elhami, M. (2015). Test of Functional Fixation Hypothesis; Case of Continuous and Non-Continuous Component of Earnings. Journal of Accounting and Auditing Studies, 14(2015):44-57. (in Persian)

Valipour, H., Rostami, V., \&Shahabi, A. (2010). The Relationship of Levels and Components of Reported Earnings to Predict the Value of the Company. Iranian Journal ofManagement Accounting, 7(2010):93-107. (in Persian)

Wan Ismail, W., Kamarurin, K., \& Sarman, S. R. (2015). The Quality of Earnings in Shariah-compliant Companies: Evidence from Malaysia. Journal of Islamic Accounting and Business Research, 6(1):19-41.

Bibliographic information of this paper for citing:

Babaie, Sasan (2021). Earnings Decomposition, Value Relevance and Predictability. Iranian Journal of Finance, 5(4), 107-127.

Copyright (C) 2021, Sasan Babaie

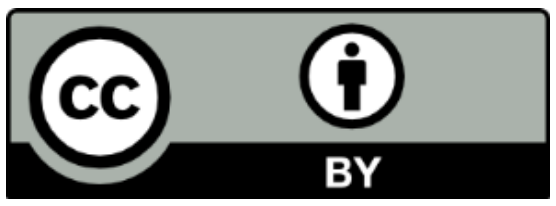

